\title{
Leucon parasiphonatus, a new species (Crustacea: Cumacea: Leuconidae) from Antarctic waters
}

\author{
U. Mühlenhardt-Siegel \\ Zoologisches Institut und Museum, Universität Hamburg; Martin-Luther-King-Platz 3, \\ D-20146 Hamburg, Federal Republic of Germany
}

\begin{abstract}
Six specimens of Leucon parasiphonatus $\mathrm{n}$. sp. were collected at depths ranging from 15 to $424 \mathrm{~m}$ in the vicinity of King George Island (South Shetland Islands, Antarctica) and the south eastern Weddell Sea. Leucon parasiphonatus belongs to the subgenus Leucon and differs from the other already known Antarctic and Subantarctic species of the genus, in the absence of a serrated dorsomedian line and in the presence of a long pseudorostrum with several fine setae at its tip, surrounding the very long branchial siphon. The surface of the carapace is granulated; the carapace displays no teeth except for a few at its antero-lateral margin and at its ventral margin. The species most similar to Leucon parasiphonatus is Leucon siphonatus, reported from Mediterranean and North Atlantic waters.
\end{abstract}

\section{INTRODUCTION}

The family Leuconidae Sars, 1878 is generally considered to consist of 7 genera with at least 60 Arctic and 22 Antarctic species (Bacescu, 1988). Bacescu (1988) lists 41 species for the genus Leucon Kröyer, 1846, including 26 polar species, 8 living in Antarctic/ Subantarctic oceans. Only two of these Antarctic species have been described latterly: Leucon inexcavatus Ledoyer, 1977, and Leucon breidensis Gamo, 1987, the other 6 species being known since the turn of the century. All of these Antarctic species belong to the subgenus Leucon.

Six specimens of an undescribed Leucon (Leucon) species were obtained during German Antarctic expeditions during the last few years.

\section{MATERIAL AND METHODS}

Three specimens of the new species were collected during German Antarctic expeditions aboard RV "Polarstern" (PS 12/2, 1987) (for list of stations see Fütterer, 1988) and "Meteor" (M 11/4, 1989/90) (for position of stations see Leitstelle Meteor, 1990) to the Antarctic Peninsular region. The sampling gear was a van Veen grab $\left(0.1 \mathrm{~m}^{2}\right.$ size $)$. Twelve stations were sampled with 10 replicate samples. The specimens of the new species were found in only 3 of 120 samples.

The area investigated is described in Mühlenhardt-Siegel $(1988,1989)$ and Leitstelle Meteor (1990). The material was fixed in $4 \%$ formalin-seawater and preserved in $70 \%$ ethanol. 
Another specimen from dredgings in the sublittoral zone of King George Island (South Shetland Islands) was provided by M. Rauschert (cf. Rauschert, 1991).

Two additional specimens from the south-eastern Weddell Sea were made available by J. Gutt.

The types and paratypes have been deposited at the Zoological Museum in Hamburg, Germany.

Holotype: Nr. ZMH 37259 a and b, adult female.

Type locality: Antarctica, South Shetland Islands, King George Island, $62^{\circ} 05.63^{\prime}$

$\mathrm{S} / 57^{\circ} 38.59^{\prime} \mathrm{W}, 363 \mathrm{~m}$, soft bottom.

D a te : January 1st, 1990.

Par a ty pes: Nr. ZMH 37260 a and b, 1 subadult male.

L o c a lity: same station as holotype, but different sample, $382 \mathrm{~m}$.

ZMH 37261, 1 subadult female (Fig. 27).

L ocality: Antarctica, South Shetland Islands, King George Island, $62^{\circ} 04.9^{\prime} \mathrm{S} / 57^{\circ}$ $39.0^{\prime} \mathrm{W}, 314 \mathrm{~m}$, soft bottom.

D a te : November 12th, 1987.

ZMH 37262: 1 subadult female, M. Rauschert leg.

Locality: Antarctica, South Shetland Islands, King George Island, near Bellingshausen station, north-east of Two Summit Island, 15 to $20 \mathrm{~m}$, pebbles.

D a t e : November 26th, 1985.

ZMH 37263: subadult male, J. Gutt leg., 74 $41^{\circ} \mathrm{S} / 38^{\circ} 15^{\prime} \mathrm{W}, 424 \mathrm{~m}$.

D a te: January 27 th, 1988.

ZMH 37264: Juvenile specimen, J. Gutt leg., same station as ZMH 37263.

\section{Leucon parasiphonatus n. sp.}

Di a g n o s is: Carapace: surface granulated, without serrated dorsomedian line, teeth on carapace lacking,

Ocellar lobus: not observed.

Pseudorostrum: long.

Siphonal tube (branchial siphon): very long; as long as carapace, even in juvenile and subadult stages.

5th abdominal segment: slightly longer than the other abdominal segments.

Endopodite of the uropod: segmented two-fold, distal segment half as long as proximal segment.

E thymology: named $L$. parasiphonatus because of its great resemblance to Leucon siphonatus.

Description: The description is based on the holotype, an adult female carrying 7 eggs in brood pouch.

Length: $3.3 \mathrm{~mm}$ (from tip of the pseudorostrum to end of the telson) (Figs 1a, b)

Eyes: missing.

Integument: thin and translucent, surface granulated.

Carapace: length $1.025 \mathrm{~mm}$; width: $0.525 \mathrm{~mm}$; no denticles or serration on dorsomedian line; a lateral ridge from base of pseudorostrum backwards to posterolateral margin of carapace. 
Pseudorostrum: long, with 6 setae on each lobus arising from the margin of the pseudorostrum.

Siphonal tube (branchial tube): very long, as long as carapace.

Antennal notch: narrow, rounded, with 3 hyaline teeth.

Ventral margin: 3 to 4 denticles in the last part of carapace.

Thorax: 5 free segments, the first segment not covered by the carapace dorsally but laterally; as long as the abdomen or slightly longer (Table 1).

Abdomen: 5th segment longer than other abdominal segments; $1 / 3$ as long as the other 4 combined.

Telson: not free.

First antenna (antennula) (Fig. 2, Fig. 27B): long, extending over the tip of the pseudorostrum; last segment of peduncle shorter than the preceding one and as long as the external flagellum. Flagellum 3 segmented, first segment longer than the second, third segment very short (Fig. 27B); inner flagellum as long as the first segment of the outer flagellum. Two different types of spines: plumose spines and annulated ones.

Second antenna (antenna): not observed, probably reduced in the female.

Mandible: small, observed from above (Fig. 3).

Maxillae 1 and 2 (Fig. 4): same as for genus in general.

Maxilliped 1 and 2 (Figs 5 and 6): same as for genus in general.

Maxilliped 3 (Fig. 7): base very broad and as long as the distal segments combined, carrying 3 long plumose setae; exopod with very long setae.

Peraeopod 1 (Fig. 8): very long, with 6 segments, width of base $1 / 3$ of the total length, carpus and propodus equal in length; exopod with long setae.

Peraeopod 2 (Fig. 9): with 6 segments, base rather stout; exopod developed.

Table 1. The morphometric characters (mm) of Leucon parasiphonatus $\mathrm{n} . \mathrm{sp}$.

\begin{tabular}{llcccc}
\hline & & \multicolumn{3}{c}{ Type number } \\
& 37259 & 37260 & 37262 & 37263 & 37264 \\
\hline & & & Sex & & \\
& Female & Male & Female & Male & Juvenile \\
\hline Branchial tube & 0.687 & 0.962 & 0.937 & 0.875 & 0.662 \\
Pseudorostrum & 0.200 & 0.187 & 0.250 & 0.187 & 0.162 \\
Carapace length & 1.025 & 1.125 & 1.125 & 0.750 & 0.625 \\
\multicolumn{1}{c}{ height } & 0.480 & 0.500 & 0.562 & 0.500 & 0.362 \\
Free thoracic segments & 0.525 & 0.250 & 0.687 & 0.500 & 0.475 \\
Thorax & 0.625 & 0.750 & 0.750 & 0.625 & 0.500 \\
Abdominal segments 1-4 & 1.650 & 1.875 & 1.875 & 1.375 & 1.125 \\
Abdominal segment 5 & 1.015 & 1.125 & 1.125 & 0.875 & 0.750 \\
Abdominal segment 6 & 0.375 & 0.500 & 0.437 & 0.375 & 0.312 \\
Abdomen & 0.250 & 0.250 & 0.275 & 0.187 & 0.162 \\
Total length & 1.650 & 1.875 & 1.837 & 1.437 & 1.225 \\
\hline
\end{tabular}




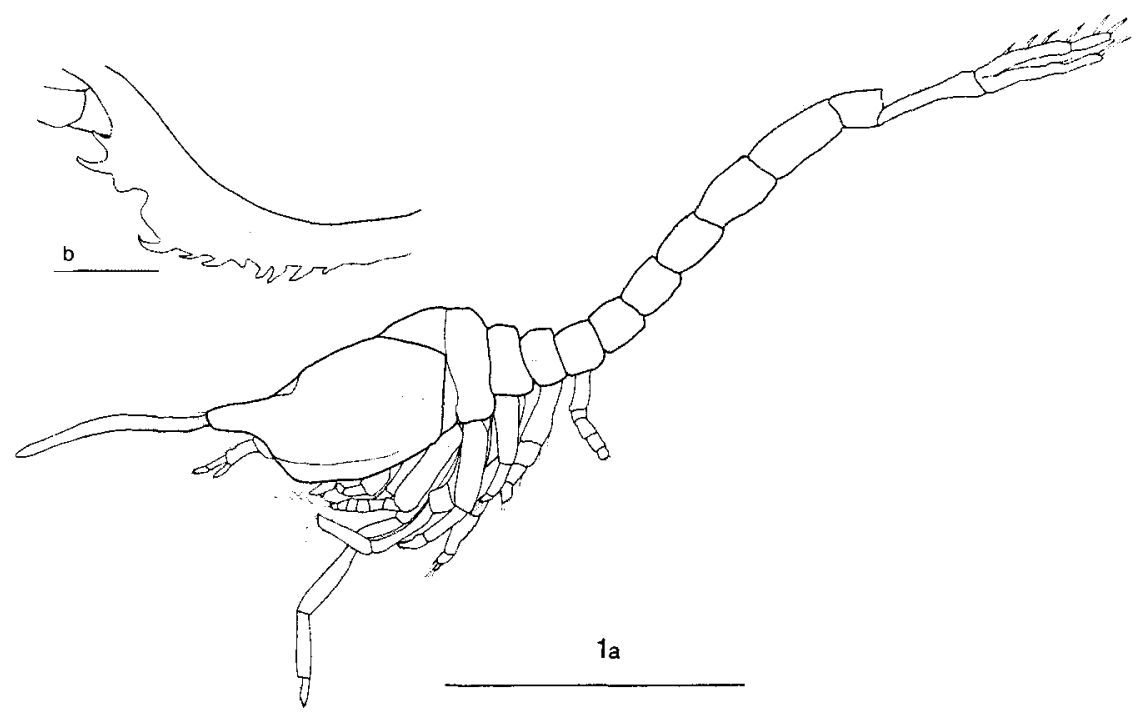

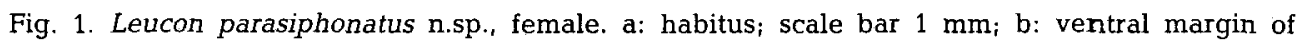
carapace; scale bar $0.05 \mathrm{~mm}$

Peraeopod 3 (Fig. 10): with 6 segments, exopod developed.

Peraeopod 4 (Fig. 11): with 6 segments, exopod absent, as is normal for family.

Peraeopod 5 (Fig. 12): with 6 segments, no exopod present, as is normal for family.

Uropods (Fig. 13): peduncle shorter than the subequal rami, 2 setae and 1 spine at inner margin. First segment of inner ramus twice as long as the distal segment. First segment with 4 stout spines on the inner margin, the distal segment with 2 spines and a long apical seta, which is plumose at the proximal part and annulated at the distal part.

The first segment of the outer ramus very short, the second segment having two fine setae at the outer margin, a spine at the inner margin, one long terminal seta with a plumose proximal part and an annulated distal part, 3 additional terminal setae.

Differences between $\mathrm{males}$ and females: The sexual differences typical for this family - the development of antenna 2, 4 pairs of exopods at peraeopods and 2 pairs of pleopods - were clearly discernible; however, not all of them were completely developed. Additional differences were observed between the holotype and a subadult male (paratype no. ZMH 37260 , length: $3.7 \mathrm{~mm}$, see Figs 14-26):

Peraeopod 1 (Fig. 21): with 6 segments; dactylus longer than in female; plumose setae at ischium, merus and carpus. Carpus and propodus are the longest segments.

Figs 2-13. Leucon parasiphonatus n.sp. female. 2: antenna 1 ; $3:$ mandible from above; 4 : maxilla 1 ; 5: maxilliped $1 ; 6$ : maxilliped $2 ; 7$ : maxilliped 3 with endopod (a) and exopod (b); 8 : peraeopod $1 ; 9$ : peraeopod $2 ; 10$ : peraeopod $3 ; 11$ : peraeopod $4 ; 12$ : peraeopod $5 ; 13: 6$ th abdominal segment telson and right uropod. Scale bars $0.1 \mathrm{~mm}$ in all figures except in Fig. 3 where it is $0.05 \mathrm{~mm}$ 


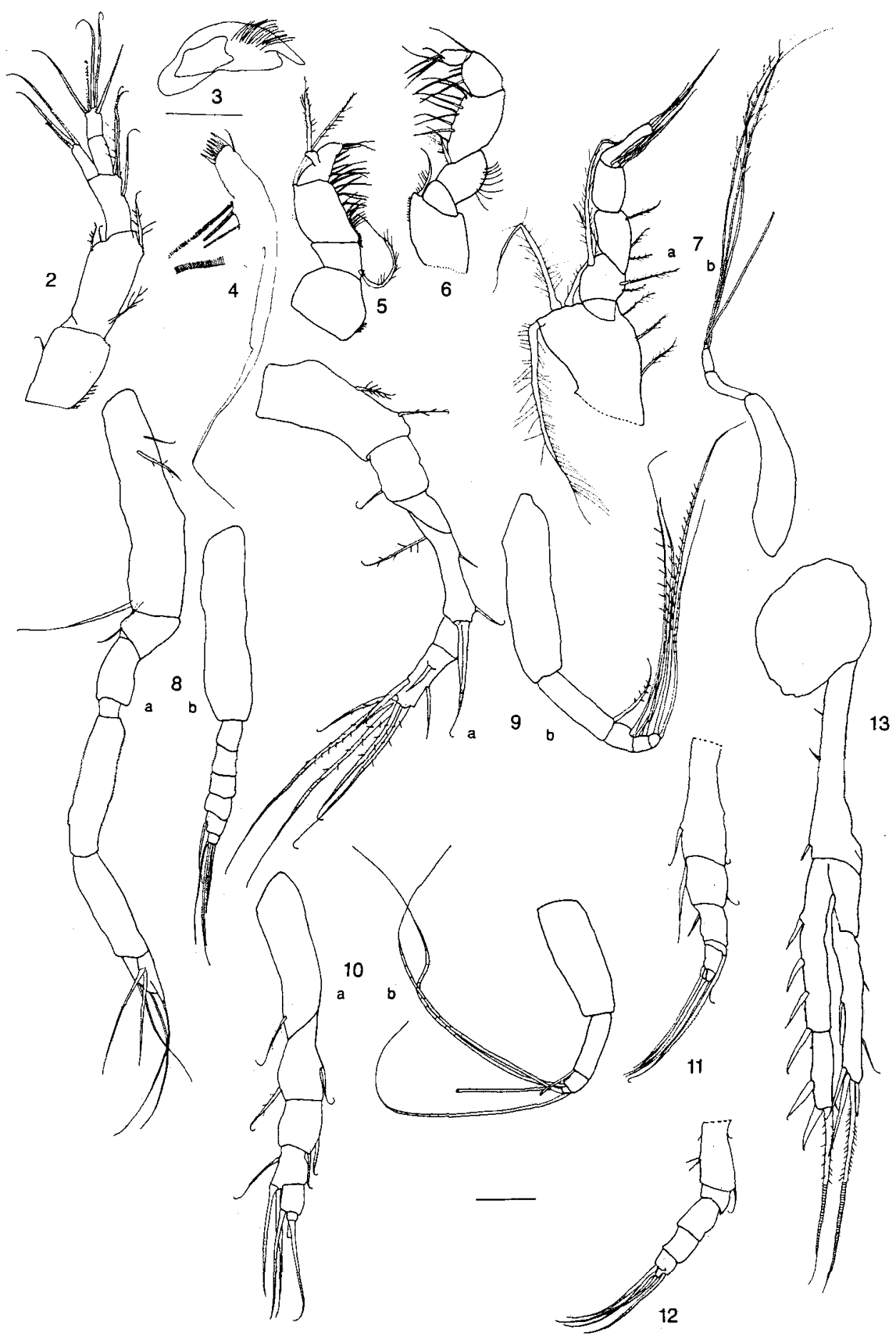




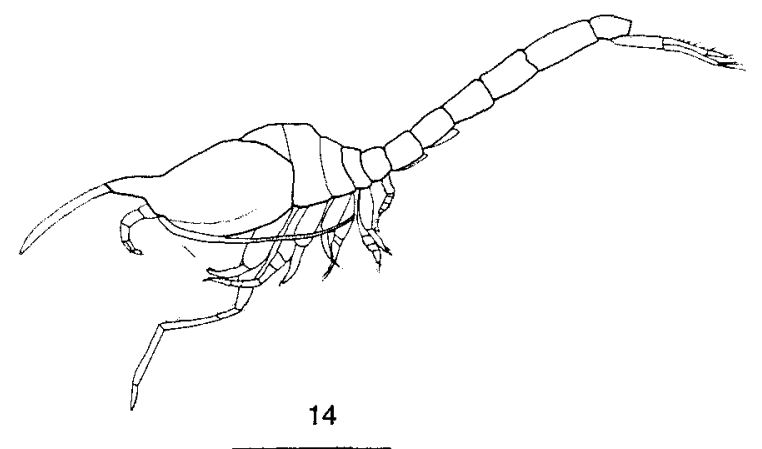

Fig. 14. Leucon parasiphonatus n.sp., male. Habitus; scale bar $1 \mathrm{~mm}$

The exopods of the peraeopods (Figs 21-24): more segmented than in female.

Peduncle of uropods (Fig. 26): stouter and with 2 setae; the proximal segment of the inner ramus with 6 spines, but no setae at the outer margin of the outer ramus.

\section{REMARKS}

The known Antarctic and Subantarctic species of the Leuconidae family are as follows:

Leucon antarctica Zimmer, 1907; L. assimilis Sars, 1887; L. breidensis Gamo, 1987; L. inexcavatus Ledoyer, 1977; L. kerguelensis Zimmer, 1908; L. sagitta Zimmer, 1907; L. septemdentatus Zimmer, 1902; L. vanhoeffeni Zimmer, 1907.

All are characterized by a serrated dorsomedian line; belong, therefore, to the subgenus Leucon. The new species presented here lacks denticles at the dorsomedian line, but has a very long siphonal tube, a long pseudorostrum. The anterolateral margin of the carapace is not serrated but has up to three hyaline teeth. According to Jones (1956), this new species should be placed in Epileucon sp.; however, Bishop (1981) redefined the genus. The absence of a serrated dorsomedian crest is no longer a criterium to separate Leucon and Epileucon; the most striking distinction between the two genera is that in Epileucon the 5th peraeonite has at least one pair of anteriorly curved ventral teeth. As the newly described species does not have these teeth on the ventral side of the 5th peraeonite it must be classified in the genus Leucon. Bacescu (1988) classified these two genera to subgenera.

Among the Leucon species that have a long siphonal tube accompanied with long stiff setae, the species bearing the most resemblance to $L$. parasiphonatus seemed to be $L$. siphonatus Calman, 1905, which is described from the Mediterranean and North Atlantic waters west of Ireland. This species differs from the one described above in having a single tooth near the tip of the cephalic lobe and several others near the base of the pseudorostrum. All teeth and denticles in several locations on the carapace described for $L$. siphonatus are missing in $L$. parasiphonatus.

The most remarkable fact is that $L$. parasiphonatus does not resemble any other member of Antarctic Leucon species, but is rather similar to Leucon siphonatus from the northern hemisphere. 


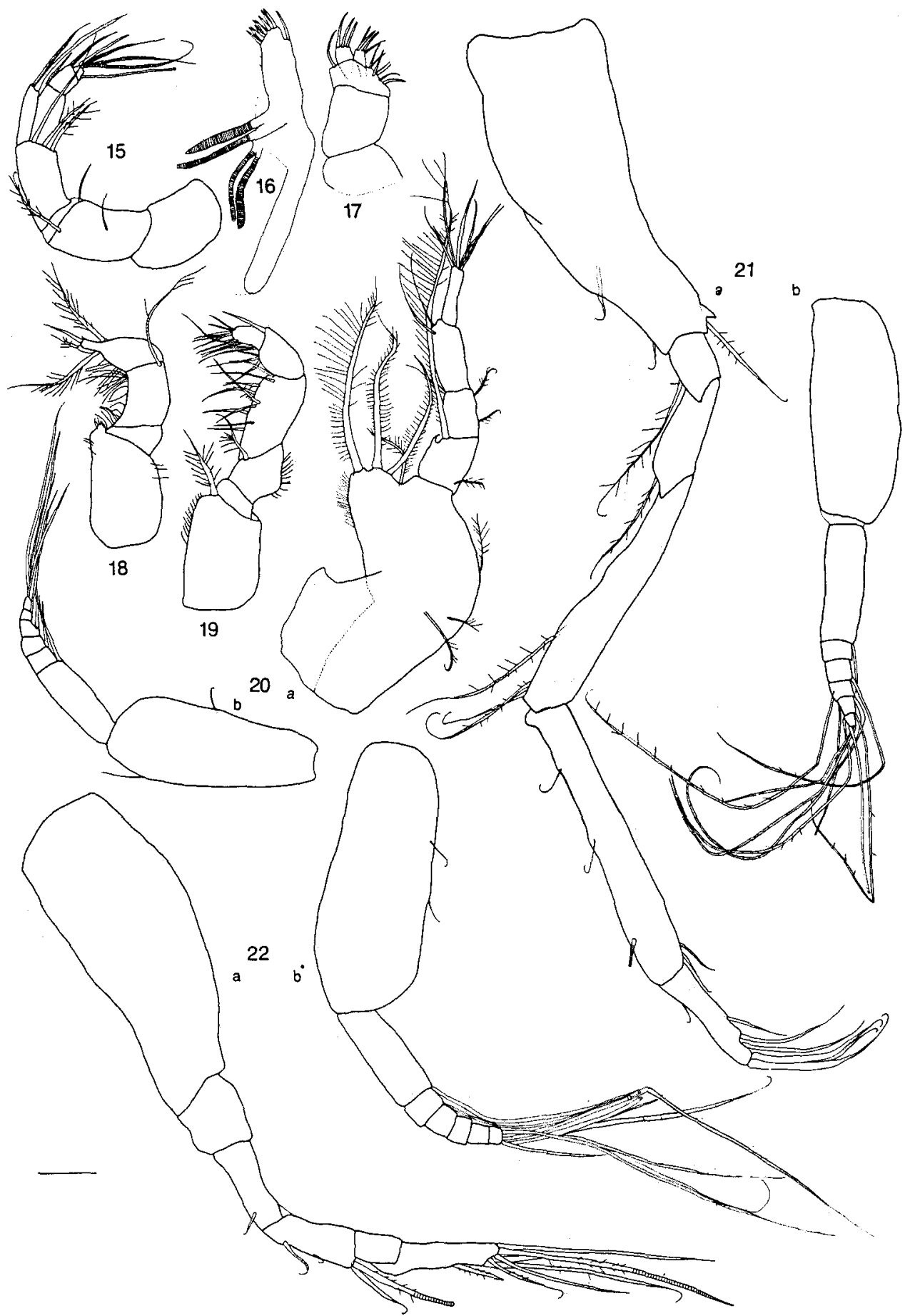

Figs 15-22. Leucon parasiphonatus n.sp., male. 15: antenna 1 ; 16 : maxilla 1 ; 17 : maxilla 2; 18 : maxilliped $1 ; 19$ : maxilliped $2 ; 20$ : maxilliped $3 ; 21$ : peraeopod $1 ; 22$ : peraeopod 2 . Scale bars $0.1 \mathrm{~mm}$ 

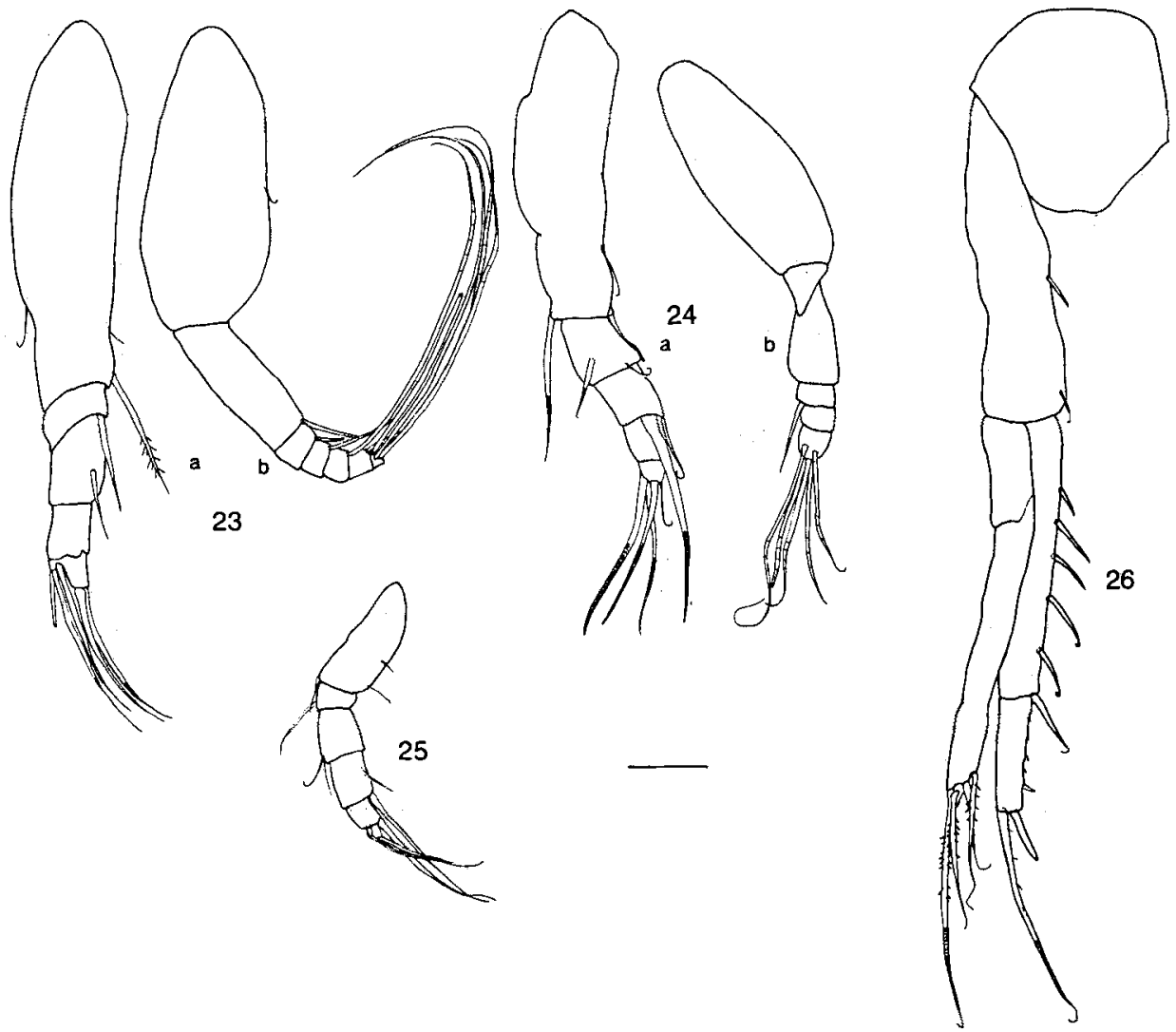

Figs 23-26. Leucon parasiphonatus n.sp., male. 23: peraeopod 3; 24: peraeopod 4; 25: peraeopod 5; 26: 6th abdominal segment telson and left uropod. Scale bars $0.1 \mathrm{~mm}$

Fig. 27. Leucon parasiphonatus n.sp, female. A: thorax habitus; B: antenna 1 and siphonaltube; C: plumose spines; D: terminal setae of peraeopod 1; E: plumose spine of antenna 1; F: plumose spine of peraeopod; G: terminal setae of peraeopod 1; H: granulated surface of carapace; F: tip of siphon; $\mathrm{K}$ : dorsomedian crest without denticles 


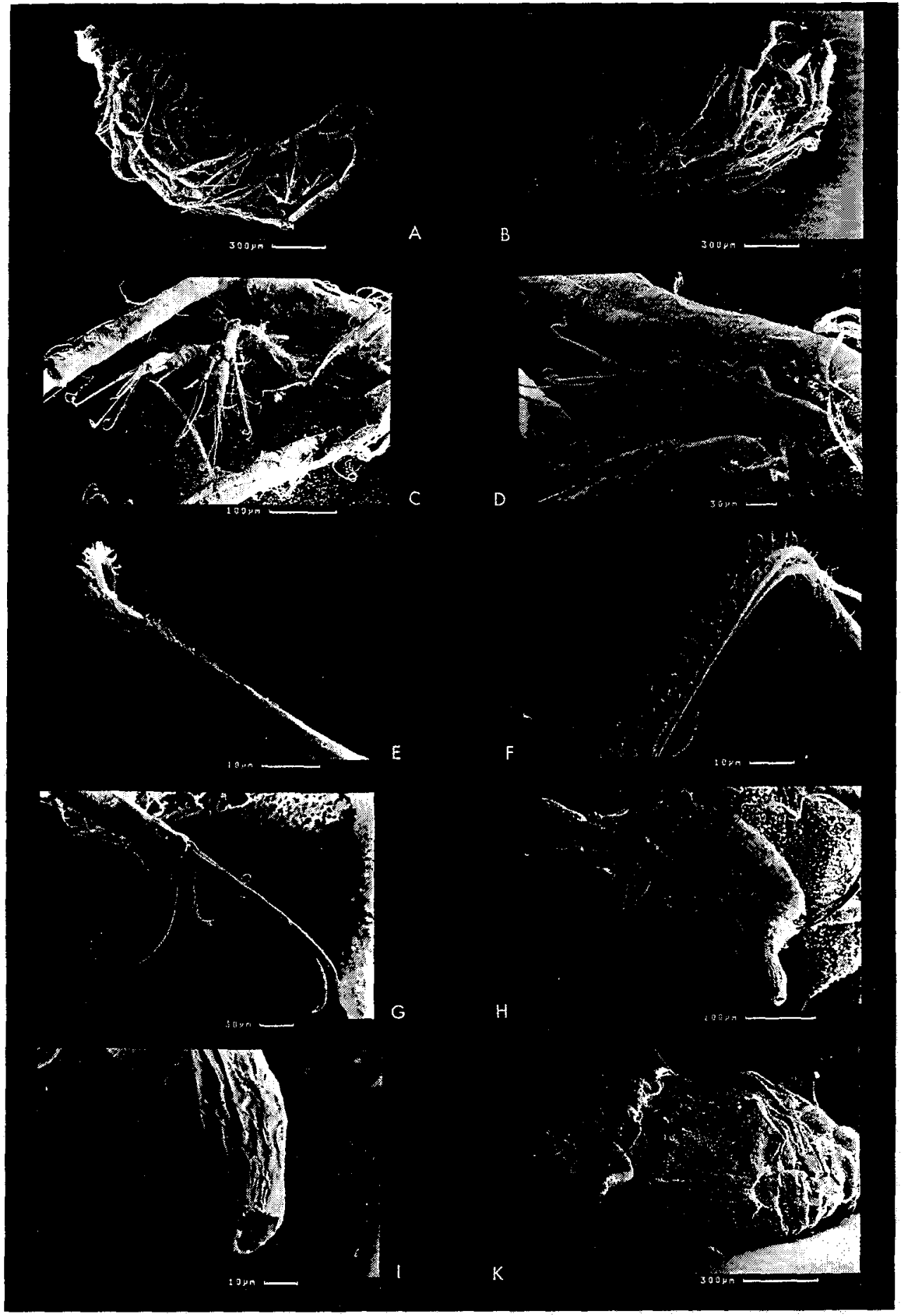


Acknowledgements. I am very grateful to my colleagues in Hamburg, Dr. H.-G. Andres, and Dr. K. Schulz, and Dipl.-Biol. H. Kapp, for critical comments; also to R. Walter and U. Harm for technical assistance, and to Dr. D. Bürkel for revising the English manuscript. I also thank Drs M. Rauschert and J. Gutt (Alfred-Wegener-Institut, Bremerhaven) for generously placing specimens of the new species at my disposal. Thanks are also due to Prof. Dr. G. Hartmann (Hamburg) for giving me the opportunity to join the Antarctic expeditions during his project that was supported by the Deutsche Forschungsgemeinschaft.

\section{LITERATURE CITED}

Bacescu, M., 1988. Cumacea 1. In: Crustaceorum Catalogus. Ed. by H.-E. Gruner \& L. B. Holthuis. Acad. Publ., The Hague, 7, 1-173.

Bishop, D. D., 1981. A revised definition of the genus Epileucon Jones (Crustacea, Cumacea), with descriptions of species from the deep Atlantic. - Phil. Trans. R. Soc. (B) 291 (1052), 353-409.

Fütterer, D. K., 1988. Die Expedition Antarktis V1 mit FS "Polarstern" 1987/88. - Ber. Polarforsch. 58, 1-267.

Jones, N. S., 1956. Cumacea from the west coast of Africa. - Atlantide Rep. 4, 183-212.

Leitstelle Meteor (Hrsg.), 1990. Südatlantik-Zirkumpolarstrom. - Forsch.-Schiff Meteor Reise 11, $1-41$.

Mühlenhardt-Siegel, U., 1988. Some results on quantitative investigations of macrozoobenthos in the Scotia Arc (Antarctica). - Polar Biol. 8, 241-248.

Mühlenhardt-Siegel, U., 1989. Quantitative investigations of Antarctic zoobenthos communities in winter (May/June) 1986 with special reference to the sediment structure. - Arch. FischWiss. 39 (Beih. 1), 123-141.

Rauschert, M., 1991. Ergebnisse der faunistischen Arbeiten im Benthal von King George Island. Ber. Polarforsch. 76, 1-75. 